\title{
E-cigarette use and respiratory disorders: an integrative review of converging evidence from epidemiological and laboratory studies
}

\author{
Thomas A. Wills ${ }^{1}$, Samir S. Soneji ${ }^{2}$, Kelvin Choi $^{3}$, Ilona Jaspers ${ }^{4}$ and \\ Elizabeth K. Tam ${ }^{5}$
}

Affiliations: ${ }^{1}$ Cancer Prevention Program, University of Hawaii Cancer Center, Honolulu, HI, USA. ${ }^{2}$ Dartmouth Institute for Health Policy and Clinical Practice, Geisel School of Medicine at Dartmouth, Hanover, NH, USA ${ }^{3}$ Division of Intramural Research, National Institute on Minority Health and Health Disparities, Bethesda, MD, USA. ${ }^{4}$ Center for Environmental Medicine, Asthma and Lung Biology, University of North Carolina School of Medicine, Chapel Hill, NC, USA. ${ }^{5}$ Dept of Medicine, John A. Burns School of Medicine, Honolulu, HI, USA.

Correspondence: Thomas A. Wills, Cancer Prevention in the Pacific Program, University of Hawaii Cancer Center, 701 Ilalo Street, Honolulu, HI 96813, USA. E-mail: twillsdacc.hawaii.edu

@ERSpublications

Epidemiological studies show a relationship of e-cigarette use with asthma and COPD, and laboratory studies show their adverse effects on four biological processes. It can be concluded that e-cigarette use is of significant concern for public health. https://bit.ly/3drH4pj

Cite this article as: Wills TA, Soneji SS, Choi K, et al. E-cigarette use and respiratory disorders: an integrative review of converging evidence from epidemiological and laboratory studies. Eur Respir J 2021; 57: 1901815 [https://doi.org/10.1183/13993003.01815-2019].

\section{ABSTRACT}

Background: Use of electronic cigarettes (e-cigarettes) is prevalent among adolescents and young adults, but there has been limited knowledge about health consequences in human populations. We conduct a systematic review and meta-analysis of results on respiratory disorders from studies of general-population samples and consider the mapping of these results to findings about biological processes linked to ecigarettes in controlled laboratory studies.

Method: We conducted a literature search and meta-analysis of epidemiological studies on the association of e-cigarette use with asthma and with COPD. We discuss findings from laboratory studies about effects of e-cigarettes on four biological processes: cytotoxicity, oxidative stress/inflammation, susceptibility to infection and genetic expression.

Results: Epidemiological studies, both cross-sectional and longitudinal, show a significant association of ecigarette use with asthma and COPD, controlling for cigarette smoking and other covariates. For asthma ( $\mathrm{n}=15$ studies), the pooled adjusted odds ratio (aOR) was 1.39 (95\% CI 1.28-1.51); for COPD ( $\mathrm{n}=9$ studies) the aOR was 1.49 (95\% CI 1.36-1.65). Laboratory studies consistently show an effect of ecigarettes on biological processes related to respiratory harm and susceptibility to illness, with e-cigarette conditions differing significantly from clean-air controls, although sometimes less than for cigarettes.

Conclusions: The evidence from epidemiological studies meets established criteria for consistency, strength of effect, temporality, and in some cases a dose-response gradient. Biological plausibility is indicated by evidence from multiple laboratory studies. We conclude that e-cigarette use has consequences for asthma and COPD, which is of concern for respirology and public health.

This article has supplementary material available from erj.ersjournals.com

Received: 23 Sept 2019 | Accepted after revision: 10 Oct 2020

The content of this work is not subject to copyright. Design and branding are copyright OERS 2021. This version is distributed under the terms of the Creative Commons Attribution Non-Commercial Licence 4.0. 


\section{Introduction}

Use of electronic cigarettes (e-cigarettes) and other types of electronic nicotine delivery systems is currently prevalent among adolescents and young adults $[1,2]$. Recent surveys show that nicotine-based e-cigarette use is common [3] and indicate that $27.5 \%$ of US high school students are current e-cigarette users [4]. This prevalence has raised concern among a broad range of public health researchers and laboratory scientists [5-8].

While there has been considerable research on the correlates of e-cigarette use $[9,10]$, there has been less knowledge about health consequences in human populations. A report compiled early in 2017 concluded there was no definitive evidence on whether e-cigarettes cause respiratory disease in humans [11]. However, since then there has been considerable evidence on health variables from epidemiological investigations of large general-population samples, from laboratory studies of biological processes linked to e-cigarettes, and from case reports based on patients who have provided examples of respiratory disease associated with e-cigarette use [12-17].

The aim of this article is to provide a comprehensive review and meta-analysis of evidence from epidemiological studies about the association of e-cigarette use with asthma and COPD in human populations and to discuss this evidence in relation to findings from controlled laboratory studies of biological processes affected by e-cigarette use. Epidemiological studies indicate findings that occur in the natural environment of the participants and allow control for potential confounders. Laboratory studies have particular evidentiary value because they use experimental methods that allow for strict causal conclusions. Our review considers data from adolescents as well as adults, because of the prognostic significance of early respiratory symptomatology for lung disease at later ages [18-20]. We do not consider research on e-cigarettes and cardiovascular disease $[21,22]$ and we do not cover research on epigenetic and intergenerational effects [23-26].

For the epidemiological evidence, we provide a comprehensive review of all available studies and provide a meta-analysis of aggregate effect sizes across studies of asthma and COPD. For laboratory research, we discuss selected studies that are most relevant for interpreting the epidemiological findings on respiratory outcomes, as detailed reviews of laboratory research are available in focused areas [27, 28]. The present article is the first to conceptually link the epidemiological findings to evidence from laboratory research and to discuss the implications of these bodies of research when considered together.

\section{Evidence from epidemiological studies}

Epidemiological studies on the association of e-cigarettes (or synonyms thereof) with asthma and COPD (or synonyms thereof) in general populations were identified through searches on PsycINFO and PubMed, contacts with other investigators, and searching abstracts from recent research meetings. The search was conducted in March 2020.

The Preferred Reporting Items for Systematic Reviews and Meta-Analyses charts (figure 1) show how exclusion and inclusion criteria were applied for identified entries on asthma and COPD. Entries were coded and evaluated for appropriateness. To be included in the review, a study had to have a large representative sample, reasonable measures of e-cigarette use and cigarette smoking, a reasonable measure of respiratory disorder, and a comparison group of nonusers of e-cigarettes and combustible cigarettes (or repeated measures of the participants). Two of the authors (TW and SS) independently examined all entries and agreed on how studies met the criteria. Of 875 entries identified for asthma, 15 studies met all inclusion criteria; of 855 entries identified for COPD, nine studies met all criteria.

Four general issues are important for interpretation of this literature. First, because combustible cigarette smoking is correlated with e-cigarette use [29-31] and is a risk factor for respiratory disease, it is crucial to control for this correlation in multivariable analyses. As noted in the tables, most of the studies did control for cigarette smoking, indicating that observed effects for e-cigarettes are not attributable to confounding with smoking. Second, when e-cigarette use and cigarette smoking are entered together in a multivariable analysis, if they both show significant contributions to respiratory disease (i.e. additive effects) then the implication is that persons who both use e-cigarettes and smoke cigarettes will be worse off than exclusive e-cigarette users or exclusive smokers. Notes about additive effects are provided in the tables. Third, it is possible that the association between smoking and respiratory disease is different for persons who use e-cigarettes (i.e. interaction effect). This may be tested by a stratified analysis or by entering a cross-product term for e-cigarettes and smoking in a multivariable analysis in addition to their main effects. Interaction tests are noted in the tables. An interaction with OR $>1$ would indicate that the association of e-cigarette use with respiratory outcomes is greater among those who smoke (i.e. synergistic effect); OR $<1$ would indicate that e-cigarette use has a greater effect among nonsmokers (i.e. inverse interaction). Fourth, with cross-sectional data, the finding of a positive association for e-cigarettes and 
a)

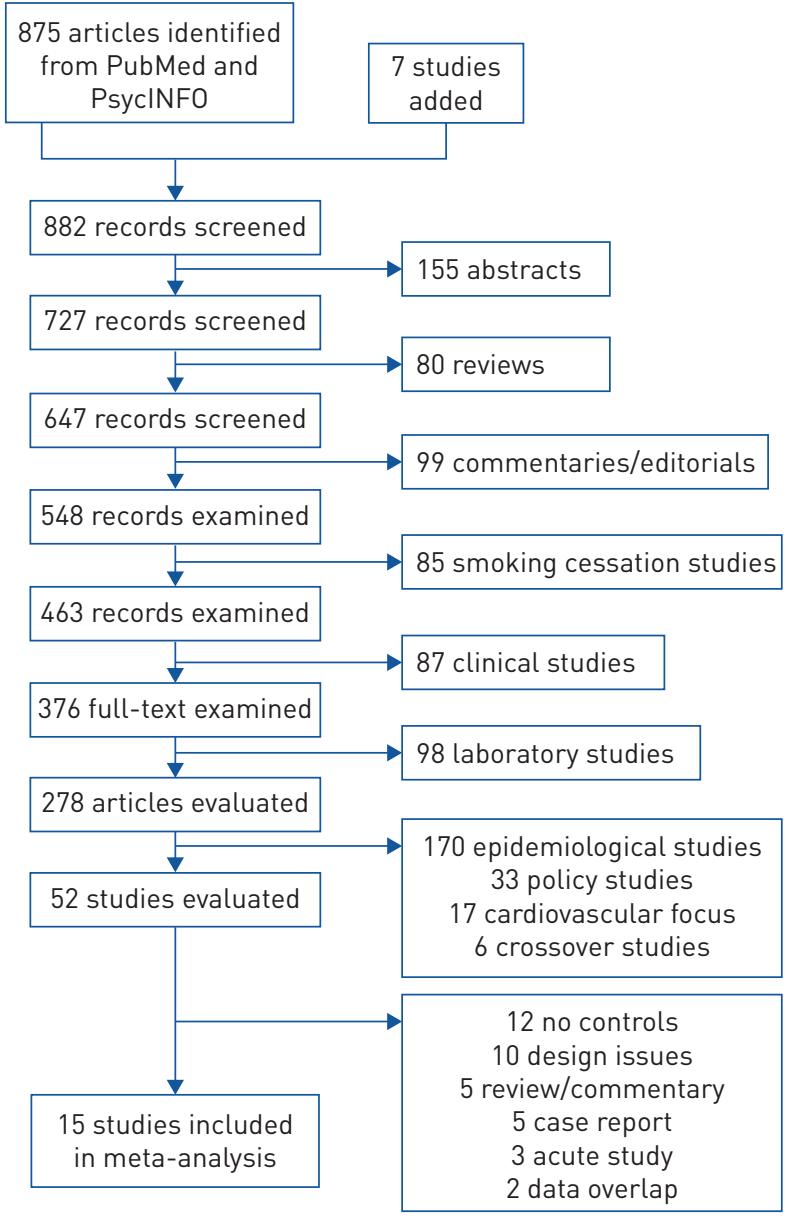

b)

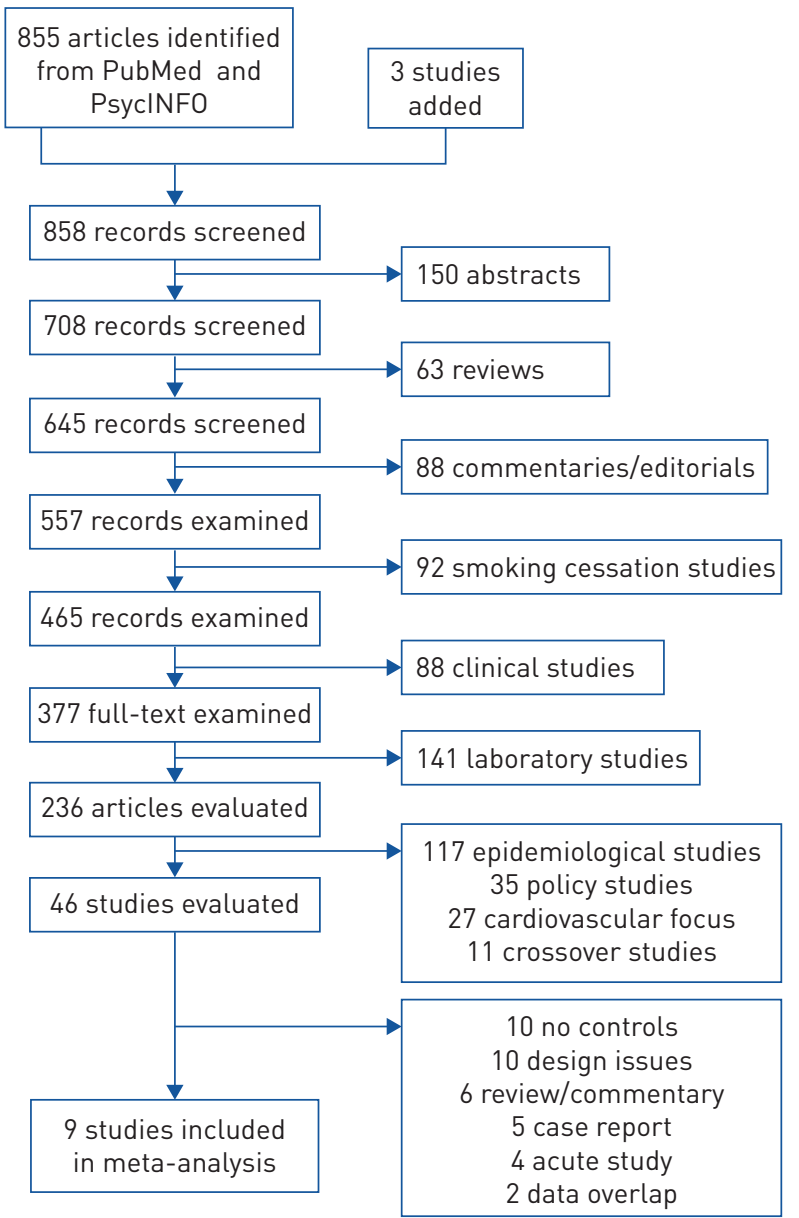

FIGURE 1 Flow chart for selection of studies al asthma; b) COPD.

respiratory disease could be interpreted as meaning that persons who develop disease quit smoking cigarettes and take up e-cigarettes (i.e. reverse causation). This possibility may be addressed in cross-sectional data through internal analyses that logically would work either for or against an interpretation of reverse causation. Alternatively, longitudinal data showing that e-cigarette use precedes disease development in time would work against a reverse-causation interpretation. This issue is addressed in the review of the studies.

\section{Epidemiological studies of asthma}

Characteristics of studies of asthma are presented in table 1. Studies of adolescents typically used school-based data collection and criterion variables indicating diagnosis of asthma by a health professional. The participants in these studies were mostly high-school students (aged 15-18 years). Studies of adults used direct interview and telephone survey methods. Multivariable analyses typically adjusted for demographics, cigarette smoking, and other relevant covariates.

\section{Asthma among East Asian adolescents}

All four studies [32-35] found the likelihood of respiratory symptoms to be significantly higher among e-cigarette users, with additive effects for e-cigarettes and smoking. CHO and PAIK [32] also reported that e-cigarette users had more days absent from school because of asthma, an external validation. KIM et al. [33] and LeE et al. [34] found significant associations of e-cigarettes with asthma in pooled samples of middle- and high-school students. $\mathrm{CHO}$ and $\mathrm{PAIK}$ [32] performed a cross-product test and found an inverse interaction: the association of e-cigarette use with asthma was significant among never-smokers, but was nonsignificant among smokers. Confirming these results, WANG et al. [35] reported a stronger association of e-cigarette use with respiratory symptoms among never-smokers. In these studies, the finding of a significant association with respiratory disease among never-smokers works against an interpretation of reverse causation. 
TABLE 1 Epidemiological studies of e-cigarette use and asthma/bronchitis

\begin{tabular}{|c|c|c|c|c|c|c|c|c|}
\hline $\begin{array}{l}\text { First author } \\
\text { [reference] }\end{array}$ & $\begin{array}{l}\text { Subjects } \mathrm{n} \\
\text { (age groupl }\end{array}$ & E-cigarette measure & Respiratory measure & Covariates & Findings & $\begin{array}{l}\text { Smoking } \\
\text { control }\end{array}$ & $\begin{array}{l}\text { Additive } \\
\text { effects }\end{array}$ & Interaction \\
\hline \multicolumn{9}{|l|}{$\begin{array}{l}\text { Adolescent } \\
\text { studies }\end{array}$} \\
\hline Сно [32] & $\begin{array}{l}35904 \text { (10th-12th } \\
\text { graders) }\end{array}$ & Ever-use, 30-day use & $\begin{array}{l}\text { Dx with asthma by doctor (past } \\
\qquad 12 \text { months) }\end{array}$ & $\begin{array}{l}\text { Smoking, demographics, } \\
\text { obesity, SHS }\end{array}$ & $\begin{array}{l}\text { aOR=2.74 for current } \\
\text { e-cigarette use } \\
\text { (never-smokers) }\end{array}$ & Yes & Yes & Inverse ${ }^{\#}$ \\
\hline KIM [33] & $\begin{array}{l}216056 \text { (7th-12th } \\
\text { graders) }\end{array}$ & 30-day use & $\begin{array}{l}\text { Dx with asthma by doctor (ever, } \\
\text { past } 12 \text { months) }\end{array}$ & $\begin{array}{l}\text { Smoking, age, demographics, } \\
\text { region, obesity, SHS, exercise }\end{array}$ & $\begin{array}{l}\text { aOR=1.13 for current } \\
\text { e-cigarette use for } \\
\text { past-year asthma }\end{array}$ & Yes & Yes & n.a. \\
\hline LeE [34] & $\begin{array}{l}58336 \text { ( } 7 \text { th-12th } \\
\text { graders) }\end{array}$ & Ever-use & $\begin{array}{l}\text { Dx with asthma by doctor (past } \\
\qquad 12 \text { months) }\end{array}$ & $\begin{array}{c}\text { Demographics, age, SES, } \\
\text { region, obesity, physical } \\
\text { activity, SHS }\end{array}$ & $\begin{array}{c}\mathrm{aOR}=1.23 \text { for past-year } \\
\text { asthma }\end{array}$ & Yes & Yes & n.a. \\
\hline WANG [35] & $\begin{array}{l}45128 \text { ( } 7 \text { th-12th } \\
\text { graders) }\end{array}$ & 30-day use & $\begin{array}{l}\text { Cough or phlegm, } 3 \text { consecutive } \\
\text { months in past } 12 \text { months }\end{array}$ & Smoking, demographics, SHS & $\begin{array}{l}\text { aOR=2.06 for current } \\
\text { e-cigarette use } \\
\text { (never-smokers) }\end{array}$ & Yes & Yes & Inverse ${ }^{\#}$ \\
\hline Сног [36] & $\begin{array}{l}36085 \text { (9th-12th } \\
\text { graders) }\end{array}$ & Ever-use, 30-day use & $\begin{array}{c}\text { Ever Dx with asthma; still have } \\
\text { asthma }\end{array}$ & $\begin{array}{c}\text { Smoking, SHS, metro status, } \\
\text { demographics }\end{array}$ & $\begin{array}{c}\mathrm{aOR}=2.20 \text { for current } \\
\text { e-cigarette use for current } \\
\text { asthma }\end{array}$ & Yes & n.a. & n.a. \\
\hline FedeLE [37] & $\begin{array}{l}32921 \text { (9th-12th } \\
\text { graders) }\end{array}$ & 30-day use & $\begin{array}{c}\text { Ever Dx with asthma + still have } \\
\text { asthma }\end{array}$ & Demographics & $\begin{array}{c}\text { aOR=1.34 for current } \\
\text { e-cigarette use, current } \\
\text { asthma }\end{array}$ & No & n.a. & n.a. \\
\hline BAYLY [38] & $\begin{array}{l}11380 \text { (6th-12th } \\
\text { graders) (with } \\
\text { asthma) }\end{array}$ & $\begin{array}{l}\text { 30-day exposure to } \\
\text { e-cigarette aerosol in } \\
\text { house or car }\end{array}$ & $\begin{array}{l}\text { Did you have an asthma attack } \\
\text { (past } 12 \text { months)? }\end{array}$ & $\begin{array}{l}\text { Demographics, individual } \\
\text { tobacco product use, SHS }\end{array}$ & $\begin{array}{c}\text { aOR=1.27 for recent aerosol } \\
\text { exposure, recent asthma } \\
\text { attack }\end{array}$ & Yes & Yes & Equal ${ }^{\text {ๆl-+ }}$ \\
\hline LARSEN [39] & $\begin{array}{l}2840 \text { (9th-12th } \\
\text { graders) }\end{array}$ & $\begin{array}{l}\text { E-cigarette use, past } \\
12 \text { months }\end{array}$ & $\begin{array}{c}\text { Ever Dx with asthma by doctor, } \\
\text { nurse }\end{array}$ & Demographics, SES & $\begin{array}{c}\mathrm{aOR}=1.78 \text { for recent } \\
\text { e-cigarette use }\end{array}$ & No & n.a. & n.a. \\
\hline Schweitzer [40] & $\begin{array}{l}6089 \text { (9th-12th } \\
\text { graders) }\end{array}$ & Ever-use, 30-day use & $\begin{array}{c}\text { Ever Dx with asthma by doctor; } \\
\text { still have asthma }\end{array}$ & $\begin{array}{c}\text { Demographics, smoking, BMI, } \\
\text { marijuana use, educational } \\
\text { plans }\end{array}$ & $\begin{array}{c}\mathrm{aOR}=1.48 \text { for current } \\
\text { e-cigarette use, current } \\
\text { asthma }\end{array}$ & Yes & Yes & Equal" \\
\hline WiLLS [41] & $\begin{array}{l}14765 \text { (9th-12th } \\
\text { graders) }\end{array}$ & Ever-use, 30-day use & $\begin{array}{c}\text { Ever Dx with asthma by health } \\
\text { professional }\end{array}$ & $\begin{array}{c}\text { Demographics, smoking, } \\
\text { obesity, marijuana use }\end{array}$ & $\begin{array}{c}\mathrm{aOR}=1.30 \text { for current } \\
\text { e-cigarette use }\end{array}$ & Yes & Yes & Equal" \\
\hline McConnell [42] & 2086 (high school) & Ever-use, 30-day use & $\begin{array}{l}\text { Chronic bronchitis past } \\
12 \text { months, wheezing or } \\
\text { whistling in chest }\end{array}$ & $\begin{array}{c}\text { Demographics, smoking, SHS, } \\
\text { parental education, housing } \\
\text { conditions }\end{array}$ & $\begin{array}{l}\mathrm{aOR}=1.71 \text { for past } \\
\text { e-cigarette use, bronchitis }\end{array}$ & Yes & Yes & n.a. \\
\hline \multicolumn{9}{|l|}{ Adult studies } \\
\hline Wang [43] & 39747 ( $\geqslant 18$ years) & 30-day use & $\begin{array}{c}\text { Ever Dx with asthma by health } \\
\text { professional }\end{array}$ & Demographics, smoking, CHD & $\begin{array}{c}\text { aOR=1.38 for current } \\
\text { exclusive e-cigarette use }\end{array}$ & Yes & Yes & n.a. \\
\hline WiLLS [44] & 8087 (18-79 years) & Ever-use, current use & $\begin{array}{c}\text { Ever Dx with asthma by health } \\
\text { professional }\end{array}$ & $\begin{array}{c}\text { Demographics, smoking, } \\
\text { obesity, SHS }\end{array}$ & $\begin{array}{c}\mathrm{aOR}=1.33 \text { for current } \\
\text { e-cigarette use in } \\
\text { nonsmokers }\end{array}$ & Yes & No & Inverse ${ }^{\#}$ \\
\hline Osel [45] & 402822 ( $\geqslant 18$ years) & Ever-use + current use & $\begin{array}{c}\text { Ever Dx with asthma + still have } \\
\text { asthma }\end{array}$ & Demographics, BMI & $\begin{array}{c}\mathrm{aOR}=1.39 \text { for } \\
\text { never-smokers }\end{array}$ & Yes & n.a. & Never ${ }^{\S}$ \\
\hline BHATTA [46] & 23760 (18-65 years) & Ever-use, current use & $\begin{array}{l}\text { Dx with asthma by health } \\
\text { professional ever (wave 1), past } \\
12 \text { months (wave } 2 \text {, wave } 3 \text { ) }\end{array}$ & $\begin{array}{c}\text { Demographics, smoking, } \\
\text { poverty status, clinical } \\
\text { variables }\end{array}$ & $\begin{array}{l}\text { aOR=1.56 for incident } \\
\text { asthma for current } \\
\text { e-cigarette use }\end{array}$ & Yes & Yes & n.a. \\
\hline
\end{tabular}

Dx: diagnosed; SHS: second-hand smoke exposure; aOR: adjusted odds ratio; n.a.: not available (data not available or test not performed); SES: socioeconomic status; BMI: body mass index; CHD: coronary heart disease. ${ }^{\#}$ : effects of e-cigarettes greater among nonsmokers; ${ }^{\text {": }}$ effect of e-cigarettes equal in smokers and nonsmokers; ${ }^{+}$: this study tested interactions of e-cigarette aerosol exposure with second-hand smoke exposure and current cigarette smoking; ${ }^{\S}$ : analysis performed only for nonsmokers. 
Statewide surveys of asthma in Florida

CHOI and BERNAT [36] reported a stronger association of e-cigarettes with asthma for current (30-day) use (adjusted (a) $\mathrm{OR}=2.20)$ than for lifetime use $(\mathrm{aOR}=1.72)$. Another study [37] reported a significant association of e-cigarette use with asthma in the whole sample in a Florida survey conducted in a different year. Two analyses focusing on adolescents with asthma found own e-cigarette use [36] or second-hand exposure to e-cigarette aerosol [38] associated with higher likelihood of having had an asthma attack during the past year.

\section{Regional and national surveys on asthma}

A Canadian study [39] noted a significant association of ever e-cigarette use with lifetime asthma and a study in Hawaii [40] found a significant association of e-cigarette use with current asthma, controlling for cigarette smoking and other covariates (e.g. obesity). Similarly, a study with a US national sample [41] indicated a significant association of e-cigarette use with asthma controlling for cigarette smoking, marijuana use and other covariates. In two studies [40, 41], e-cigarette use and cigarette smoking made additive contributions to likelihood of asthma; cross-product tests for interaction between e-cigarette and cigarette smoking were mostly nonsignificant.

\section{Bronchitis among high-school students}

In a California study [42], chronic bronchitis was coded if in the previous 12 months a participant had daily cough, congestion or phlegm for 3 months in a row other than when having a cold. An analysis for the total sample showed significant associations of both e-cigarette use and smoking with chronic bronchitis and also showed a dose-response effect: the likelihood of bronchitis was higher with more frequent e-cigarette use. A significant association of e-cigarette use with bronchitis among never-smokers was noted, but a comparable analysis for smokers was not reported.

\section{E-cigarette use and asthma among adults}

In a national web-based survey conducted from 2013 through 2017 [43], current e-cigarette use was positively associated with a diagnosis of asthma and with a breathing-difficulty score. In Hawaii data from the Behavioral Risk Factor Surveillance Survey (BRFSS), e-cigarette use was significantly associated with asthma only among nonsmokers [44], similar to findings from three adolescent studies [32, 35, 42]. OsEI et al. [45] pooled data from 2 years of national BRFSS data and noted a significant association of current e-cigarette use with current asthma among persons who had never smoked. They also noted a doseresponse effect: a greater likelihood of asthma with more frequent e-cigarette use. BHATTA and GLANTz [46] used longitudinal data from a national household interview study, the Population Assessment of Tobacco and Health (PATH), to predict incident (i.e. new) asthma at waves 2 and 3 among persons who were free of asthma at wave 1 . There was a significant relationship of baseline e-cigarette use to incident asthma in this prospective analysis.

\section{Epidemiological studies of COPD}

In studies of respiratory disorder among adults (table 2), the criterion variable typically involved having been diagnosed with COPD (and sometimes other respiratory conditions) by a doctor, nurse or other health professional. Seven studies were cross-sectional and two were longitudinal. Multivariable analyses adjusted for covariates similar to those used for asthma, including demographics, cigarette smoking and obesity.

\section{US national sample (PATH)}

In an analysis of PATH data [47], participants were classified as nonusers, exclusive e-cigarette users, exclusive smokers or dual users. Respiratory disease was coded if a respondent said they been told by a doctor they had any of COPD, chronic bronchitis, emphysema or asthma. Results showed that current exclusive e-cigarette users had a higher likelihood of respiratory disease compared with nonusers, and dual users had an even higher likelihood. Another analysis of PATH data using a propensity-matching design to control for a range of confounders [48] showed that current e-cigarette users had a higher likelihood of COPD compared with matched controls and a stratified analysis showed an inverse interaction: a much stronger association of e-cigarette use with COPD among nonsmokers compared with the rest of the sample. Li et al. [49] analysed seven specific symptoms of respiratory illness (e.g. wheezing, dry cough) in wave 2 PATH data. They found that exclusive e-cigarette use was positively related to most of the symptoms and this was not accounted for by smoking history. Dual users had greater risk for respiratory symptomatology compared with solo e-cigarette users (i.e. additive effects).

Data from a US national sample [43] indicated current exclusive e-cigarette use was significantly associated with diagnosed COPD, with the greatest likelihood of COPD found among dual users. A study with 


\begin{tabular}{|c|c|c|c|c|c|c|c|c|}
\hline $\begin{array}{l}\text { First author } \\
\text { [reference] }\end{array}$ & $\begin{array}{l}\text { Subjects } \mathrm{n} \\
\text { lage groupl }\end{array}$ & $\begin{array}{l}\text { E-cigarette } \\
\text { measure }\end{array}$ & Respiratory measure & Covariates & Findings & $\begin{array}{l}\text { Smoking } \\
\text { control }\end{array}$ & $\begin{array}{l}\text { Additive } \\
\text { effects }\end{array}$ & Interaction \\
\hline WANG [43] & $\begin{array}{c}39747 \\
(\geqslant 18 \text { years) }\end{array}$ & 30 -day use & $\begin{array}{c}\text { Ever Dx with COPD by doctor or } \\
\text { nurse }\end{array}$ & $\begin{array}{l}\text { Demographics, } \\
\text { smoking, CHD }\end{array}$ & $\begin{aligned} \mathrm{aOR}=1.53 \text { for current exclusive } \\
\text { e-cigarette users }\end{aligned}$ & Yes & Yes & n.a. \\
\hline WiLLS [44] & 8085 ( $\geqslant 18$ years $)$ & $\begin{array}{c}\text { Ever-use, current } \\
\text { use }\end{array}$ & $\begin{array}{l}\text { Ever Dx with COPD by doctor, } \\
\text { nurse, other health professional }\end{array}$ & $\begin{array}{l}\text { Demographics, } \\
\text { smoking, SHS, BMI, } \\
\text { stress }\end{array}$ & $\begin{array}{c}\mathrm{aOR}=2.58 \text { for whole sample, } \\
2.98 \text { for nonsmokers }\end{array}$ & Yes & Yes & Inverse ${ }^{\#}$ \\
\hline StRong [47] & $\begin{array}{l}32320 \\
(\geqslant 18 \text { years })\end{array}$ & $\begin{array}{l}\text { Current } \\
\text { established user } \\
\text { (cigarette or } \\
\text { e-cigarette) }\end{array}$ & $\begin{array}{l}\text { Ever Dx by doctor, other health } \\
\text { professional with COPD, chronic } \\
\text { bronchitis, asthma or emphysema }\end{array}$ & $\begin{array}{l}\text { Demographics, other } \\
\text { tobacco product use, } \\
\text { marijuana use }\end{array}$ & $\begin{array}{l}\text { aOR=1.39 for solo e-cigarette } \\
\text { users, } a 0 R=2.07 \text { for dual users }\end{array}$ & Yes & Yes & Equal ${ }^{\text {ๆ.+ }}$ \\
\hline Perez [48] & $\begin{array}{l}2727 \text { for case- } \\
\text { control } \\
\text { (18-64 years) }\end{array}$ & $\begin{array}{c}\text { Current e-cigarette } \\
\text { user }\end{array}$ & $\begin{array}{l}\text { Ever Dx by health professional with } \\
\text { bronchitis, emphysema or COPD }\end{array}$ & $\begin{array}{l}\text { SHS, BMI, other } \\
\text { tobacco product use, } \\
\text { health measures }\end{array}$ & $\begin{array}{l}\text { aOR=1.47 for total sample, } \\
\mathrm{aOR}=2.94 \text { for nonsmokers }\end{array}$ & Yes & n.a. & Inverse \\
\hline LI [49] & $\begin{array}{c}28171 \\
(\geqslant 18 \text { years })\end{array}$ & $\begin{array}{l}\text { Current } \\
\text { established } \\
\text { e-cigarette user }\end{array}$ & $\begin{array}{l}\text { Wheezing, whistling, coughing, past } \\
12 \text { months ( } 7 \text { items) }\end{array}$ & $\begin{array}{l}\text { Demographics, BMI, } \\
\text { SHS, asthma, mental/ } \\
\text { physical health }\end{array}$ & $\begin{array}{c}\text { Solo e-cigarette users at more } \\
\text { risk than nonusers, aORs 1.37- } \\
\text { 1.78; for dual users, aORs } \\
2.32-3.58\end{array}$ & Yes & Yes & n.a. \\
\hline OsEl [50] & $\begin{array}{c}705159 \\
(\geqslant 18 \text { years) }\end{array}$ & $\begin{array}{c}\text { Current e-cigarette } \\
\text { use }\end{array}$ & $\begin{array}{l}\text { Ever Dx by health professional with } \\
\text { emphysema, bronchitis or COPD }\end{array}$ & $\begin{array}{l}\text { Demographics, poverty } \\
\text { status }\end{array}$ & $\begin{array}{c}\mathrm{aOR}=1.75 \text { for all cases, } \\
\mathrm{aOR}=2.64 \text { for never-smoker/ } \\
\text { daily user }\end{array}$ & Yes & Yes & Inverse ${ }^{\#}$ \\
\hline Hedman [51] & $\begin{array}{l}6519 \text { and } 23753 \\
\text { (20-75 years) }\end{array}$ & $\begin{array}{l}\text { Use daily or } \\
\text { sometimes }\end{array}$ & $\begin{array}{l}\text { Long-standing cough, phlegm or } \\
\text { wheeze in past } 3 \text { months, } \\
12 \text { months }\end{array}$ & $\begin{array}{l}\text { Demographics, age, } \\
\text { survey }\end{array}$ & $\begin{array}{c}\text { For any respiratory symptom, } \\
\text { aOR=1.46 for exclusive } \\
\text { e-cigarette users; aOR=4.03 for } \\
\text { dual users }\end{array}$ & Yes & Yes & n.a. \\
\hline B HATTA [46] & $\begin{array}{c}23760 \\
(18-65 \text { years) }\end{array}$ & $\begin{array}{c}\text { Ever-use, current } \\
\text { use }\end{array}$ & $\begin{array}{l}\text { Dx by doctor, other health } \\
\text { professional with emphysema, } \\
\text { bronchitis or COPD ever (wave 1), } \\
\text { past } 12 \text { months (wave 2, wave } 3 \text { ) }\end{array}$ & $\begin{array}{l}\text { Demographics, } \\
\text { smoking, poverty } \\
\text { status, clinical } \\
\text { variables }\end{array}$ & $\begin{array}{l}\text { aOR=1.29 for incident } \\
\text { respiratory disease for current } \\
\text { e-cigarette use at wave } 1\end{array}$ & Yes & Yes & n.a. \\
\hline BoWLER [52] & $\begin{array}{l}3536 \text { smokers } \\
\text { (45-80 years) }\end{array}$ & $\begin{array}{l}\text { Ever-use, current } \\
\text { (monthly, weekly, } \\
\text { daily) use }\end{array}$ & $\begin{array}{l}\text { Repeated measures of spirometry, } \\
\text { bronchitis, COPD exacerbations }\end{array}$ & $\begin{array}{l}\text { Demographics, } \\
\text { smoking, baseline } \\
\text { clinical variables }\end{array}$ & $\begin{array}{l}\text { E-cigarette users had more } \\
\text { bronchitis, more COPD } \\
\text { exacerbations, decline in lung } \\
\text { function over time }\end{array}$ & Yes & Yes & n.a. \\
\hline
\end{tabular}

Dx: diagnosed; CHD: coronary heart disease; aOR: adjusted odds ratio; n.a.: not available (data not available or test not performed); SHS: second-hand smoke exposure; BMI: body mass index. "\#: effects of e-cigarettes greater among nonsmokers; ${ }^{\uparrow}$ : effect of e-cigarettes equal in smokers and nonsmokers; ${ }^{+}$: in this study, interactions of marijuana with e-cigarette use were tested. 
BRFSS data from Hawaii [44] found a significant inverse interaction: the association of exclusive e-cigarette use with COPD was stronger among nonsmokers compared with smokers. Analysis of national BRFSS data based on both ever- and current e-cigarette use [50] also showed an association of e-cigarette use with COPD that was stronger among nonsmokers than among smokers. This study reported a doseresponse effect and emphasised that dual users were notably worse off for COPD.

\section{Respiratory symptoms in regional samples from Sweden}

Data from Sweden [51] included measures tapping occurrence of five specific respiratory symptoms (e.g. long-standing cough, sputum production). Among never-smokers, the association of e-cigarette use with likelihood of respiratory symptoms was marginally significant, but this may have been influenced by small cell size, as the overall rate of e-cigarette use in this sample was relatively low ( $2 \%$ of the population). Stratified analyses suggested e-cigarette use adding to risk among both former smokers and current smokers, but direct tests for additive effects were not conducted.

\section{Longitudinal studies of respiratory disease}

Prospective analyses of wave 1 through wave 3 PATH data [46] tested the relationship of e-cigarette use at baseline to new disease at follow-up (chronic bronchitis, emphysema or COPD) among persons who were free of disease at wave 1. Significant predictive effects were found for both prior and current e-cigarette use. Tests for additive effects indicated dual users were significantly worse off than exclusive e-cigarette users or exclusive smokers $(\mathrm{aOR}=3.30)$. In the COPDGene study [52], participants were aged 45-80 years and had $\geqslant 10$ pack-years of smoking history. Respiratory disease status was indexed at baseline through lung function tests and self-report of chronic bronchitis and COPD; follow-up measures were obtained at 6-month intervals. Longitudinal analyses controlling for baseline clinical variables indicated e-cigarette use was related to a higher prevalence of chronic bronchitis and an increased number of COPD exacerbations. Participants who used e-cigarettes were more likely to have progression of lung disease on lung function tests, although this was nonsignificant with adjustment for covariates.

\section{Meta-analysis}

The meta-analysis was based on adjusted odds ratios for e-cigarette use that controlled for cigarette smoking and other disease-related risk factors (compare with [10]). The meta-analysis for asthma was based on 11 studies of adolescents and four studies of adults (table 1) having a total of 971278 participants. A random effects meta-analysis indicated the pooled aOR for asthma was 1.39 (95\% CI 1.281.51) for e-cigarette users compared to non-e-cigarette users (figure 2a). We observed moderate heterogeneity in the results $\left(\mathrm{Q}_{14}=28.20, \mathrm{p}=0.01 ; \mathrm{I}^{2}=50 \%\right)$, because the international studies exhibited greater heterogeneity than US-based studies. A separate meta-analysis of the four adult studies indicated a significant aOR of 1.40 (95\% CI 1.23-1.58, data not shown) hence it was appropriate to include these with the adolescent studies.

The meta-analysis for COPD or composite respiratory symptoms was based on nine studies of adults (table 2) having a total of 1023494 participants. A random-effects meta-analysis indicated the pooled aOR for respiratory disease was 1.49 (95\% CI 1.36-1.65) for e-cigarette users compared to non-e-cigarette users (figure $2 \mathrm{~b})$. We observed no significant evidence of heterogeneity in these studies $\left(\mathrm{Q}_{8}=6.41, \mathrm{p}=0.60\right.$; $\mathrm{I}^{2}=0 \%$ ). (A sensitivity analysis supporting these findings is presented in the supplementary material.)

\section{Summary of epidemiological studies}

A significant association of e-cigarette use with respiratory disorder was found across 23 of the 24 studies reviewed, and e-cigarette use typically added independently to risk derived from cigarette smoking. The studies had large representative samples drawn from multiple states and countries, and the analyses included a number of covariates so as to rule out several possible types of confounding. Methodological characteristics of the research were generally strong, and independent methodological studies have supported both the validity of self-reports of substance use $($ e.g. $[53,54])$ and the reliability and validity of health measures in large-scale surveys for adolescents [55, 56] and for adults [57-59]. Moreover, several studies provided external validation for self-report findings (e.g. through school absences); this makes interpretation of the findings as deriving from an "ill worker's effect" (i.e. persons with disease simply reporting a stereotypic cause) not very plausible. A limitation that could be noted is that most studies were cross-sectional. However, a reverse-causality interpretation is not very plausible, because several cross-sectional studies showed a significant association of e-cigarette use with respiratory disease among never-smokers; and longitudinal studies showing e-cigarette use to predict onset of respiratory disease from a disease-free baseline $[46,52]$ also make reverse causation unlikely. 
a)

First author (year) [ref.] OR $(95 \% \mathrm{CI})$

Сно (2016) [32]

CHOI (2016) [36]

$2.74(1.30-5.78)$

WANG (2016) [35]

$2.20(1.47-3.30)$

LARSEN (2016) [39]

$2.06(1.24-3.42)$

$1.78(1.15-2.76)$

MCCONNELL (2017) [42]

BHATTA [2020] [46]

$1.71(1.20-2.43)$

SCHWEITZER (2017) [40]

OSEI (2019) [45]

WANG (2018) [43]

FEDELE (2016) [37]

WILLS (2019) [44]

WILLS (2020) [41]

BAYLY (2019) [38]

LEE (2019) [34]

KIM (2017) [33]

Total

Heterogeneity:

Chi-squared $_{14}=28.20(p=0.01), I^{2}=50 \%$
$1.56(1.10-2.22)$

$1.48(1.26-1.74)$

$1.38(1.09-1.75)$

$1.34(1.15-1.57)$

$1.33(1.00-1.77)$

$1.30(1.10-1.53)$

$1.27(1.10-1.46)$

$1.23(1.00-1.52)$

$1.13(1.01-1.26)$

$1.39(1.28-1.51)$

$$
0.2
$$

$1.39(1.15-1.68)$

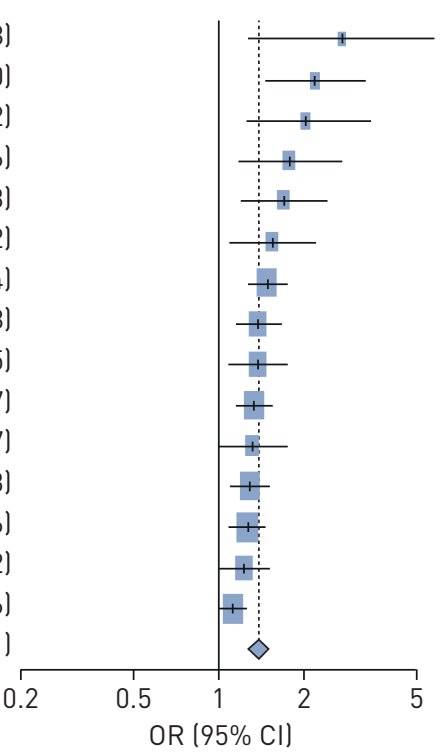

b)

First author (year) [ref.] OR (95\% CI)

\begin{tabular}{|c|c|c|}
\hline WiLLS (2019) [44] & $2.58(1.36-4.89)$ & : \\
\hline OSEI (2020) [50] & $1.75(1.25-2.45)$ & 1 \\
\hline LI (2019) [49] & $1.67(1.26-2.21)$ & \\
\hline BowLER (2017) [52] & $1.58(1.10-2.27)$ & \begin{tabular}{c:c}
1 \\
\hdashline
\end{tabular} \\
\hline WANG (2018) [43] & $1.53(1.07-2.19)$ & 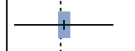 \\
\hline Perez (2019) [48] & $1.47(1.21-1.79)$ & \\
\hline HEDMAN (2018) [51] & $1.46(0.93-2.29)$ & \\
\hline STRONG (2018) [47] & $1.39(1.09-1.77)$ & \begin{tabular}{l|l}
1 \\
\end{tabular} \\
\hline ВHATTA [2020] [46] & $1.29(1.03-1.61)$ & 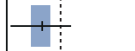 \\
\hline Total & $1.49(1.36-1.65)$ & $\diamond$ \\
\hline \multicolumn{3}{|c|}{ Heterogeneity: } \\
\hline \multicolumn{2}{|c|}{ Chi-squared $_{8}=6.41(p=0.60), I^{2}=0 \%$} & 2 \\
\hline
\end{tabular}

FIGURE 2 Forest plots for meta-analysis of studies a) asthma; b) COPD.

\section{Evidence from laboratory studies}

Laboratory studies provide experimental evidence about effects of e-cigarettes on four types of biological processes that are linked to respiratory outcomes. While other processes are possibly implicated, such as fine particulate matter $[60,61]$, these are the areas where the most direct evidence is available. We discuss representative laboratory studies on these topics because extensive narrative reviews are available elsewhere $[27,28,62]$. We note that although nicotine itself has adverse effects on pulmonary variables [63, 64], in a number of studies the effects observed for e-cigarettes are independent of nicotine content, hence are attributable to other components of e-cigarette liquid or aerosol. In our discussion we do not address the question of whether e-cigarettes have lower levels of carcinogenic toxicants associated with combustible cigarettes. While this tends to be the case for known carcinogens (e.g. [65]), there are conditions where effects of e-cigarettes on other biological processes are comparable to those of cigarettes and there is evidence that new types of toxicants may emerge from the mixing and heating of e-cigarette humectants and flavourings [66]. Thus, we believe a key question is whether effects of e-cigarettes on biological processes differ significantly from clean-air controls, indicating actual harm to lung/airway tissues. In addition, we consider how levels of biological effects differ for e-cigarettes and cigarettes.

\section{Cytotoxic effects}

In [67], cells exposed for 1-48 h to e-cigarette aerosol extracts showed concentration-dependent cytotoxic effects and reduced cell proliferation for five of the 11 products tested (supplementary table S5). LEIGH et al. [68] found that cell metabolic activity and viability were both decreased in the e-cigarette condition compared to an air control. Another study [69] found that all e-cigarette brands tested had cytotoxic effects. In one study [67], effects for e-cigarettes were sometimes less than for cigarettes, but in another [69], the effect for DNA damage was comparable to that for cigarettes. Rowell et al. [70] found that e-cigarettes produced decreases in cell viability, proliferation and metabolism compared with the control condition, and a study with JUUL brand e-cigarettes showed that pod fluids were cytotoxic in two assays for all flavours [71]. In these studies, cinnamon, menthol, vanilla and berry or fruit flavourings were found to have particularly cytotoxic effects.

In one recent study, most of the 20 popular e-liquids screened showed evidence of significant toxicity [72]. EsCOBAR et al. [73] tested the effects of three aerosolised humectants (propylene glycol, glycerol and propylene glycol + glycerol) with no flavourings added. Evidence of cytotoxicity was found for aerosolised humectants and evidence was found for increases in two pro-inflammatory cytokines, interleukin (IL)-6 and IL-8, and indices of cellular stress. Thus, evidence was found for biological effects of basic constituents of e-cigarettes, aside from contributions from flavourings. 
Oxidative stress and inflammation

Oxidative stress is an important process in the aetiology of lung disease [74], and a number of studies have shown e-cigarettes to be related to indices of oxidative stress (supplementary table S6). In studies including both human cells and animal models [75], oxidative stress was increased and cell viability decreased in the e-cigarette condition compared to a clean-air control. Other studies have also found an impact of e-cigarettes on oxidative stress and effects for disrupting lung functioning, with some effects independent of flavourings [76, 77]. Studies by LERNER et al. [78] showed that exposure to e-cigarettes reduced cell viability, increased reactive oxygen species and produced an increase in the inflammatory cytokines IL-6 and IL-8 (compare with [79]). LARCOMBE et al. [80] found that mice exposed to e-cigarette aerosol had impaired lung function and changes in airway reactivity. Effects for e-cigarettes were less than for cigarettes $[75,76]$, but in other studies $[78,80]$ some effects were comparable to or greater than those for cigarettes. An in vivo study based on human nonsmokers [81] found increases over time in blood markers for oxidative stress and inflammation and evidence that oxidants were released into the blood (compare with [82]). A cell study with human alveolar macrophages [83] found a dose-dependent reduction in cell viability (i.e. e-cigarettes increased cytotoxicity) together with increase in the production of reactive oxygen species and pro-inflammatory cytokines (e.g. IL-6, tumour necrosis factor- $\alpha$ ) and decrease in phagocytosis (i.e. bacteria-killing) ability. Notably, some studies found that heating of e-liquids increased the magnitude of adverse effects.

\section{Linkages to immune function and susceptibility to infection}

In a mixed-methods study [84], cells cultured with various concentrations of e-liquid and inoculated with human rhinovirus had higher levels of viral load and decreased host defence molecule expression, and infected mice exposed to e-cigarettes showed higher viral load (supplementary table S7). Studies with macrophages and an animal model [85] indicated that e-cigarette exposure reduced antimicrobial activity, and a controlled-infection study with mice indicated greater methicillin-resistant Staphylococcus aureus bacterial burden and higher mortality in the e-cigarette condition. In a series of cell studies and in vivo studies [86], lungs of mice exposed to e-cigarette aerosol and infected with Streptococcus pneumoniae showed increased bacterial burden, and mice infected with influenza virus showed a higher rate of mortality in the e-cigarette condition compared to a clean-air control. Similarly, GiLPIN et al. [87] and GómEz et al. [88] exposed macrophages and several types of bacteria (e.g. influenza, pneumonia) to e-cigarette aerosol extract and found increased bacterial virulence and inflammatory potential as well as decreased bacteria-killing ability. A mouse study [89] found similar effects for macrophages and found increased morbidity and mortality among influenza-infected animals, independent of nicotine. Human studies [90] have found that e-cigarette users showed markers for increased oxidative stress and inflammatory response and aberrant neutrophil activation and mucus ratios, all of which could be involved in respiratory disease (compare with [91]). In another study, proteins associated with membrane formation and mucus formation were uniquely affected in e-cigarette users so as to increase susceptibility to respiratory infections [92]. CLAPP et al. [93] found a suppressed host defense mechanism: exposure to one e-liquid reduced the motility and the beat frequency of lung cilia, hence impairing an essential respiratory defence mechanism, similar to effects found by GARCIA-Arcos et al. [91]. Although these studies demonstrated effects of flavourings, some also found significant adverse effects for humectants alone. In several studies [87-92] some effects of e-cigarettes on immune function were less than for cigarettes, but some were equal to cigarettes.

In the most recent studies, four common flavouring chemicals affected human neutrophils, an important part of the innate immune response, in a dose-dependent manner [94] and three of the four flavourings impaired defence against $S$. aureus. Similarly, CORRIDEN et al. [95] exposed neutrophil cells and mice to e-cigarette aerosol and found that exposure reduced several measures of neutrophil function and increased the number of bacteria found at an infection site. In a related study [96], proteases linked to respiratory disease were elevated in both e-cigarette users and smokers. Related effects were found in two other studies [97, 98].

\section{Genetic effects}

Yu et al. [99] found that exposure to e-cigarette aerosol produced increased cell death and DNA damage compared to untreated cells (supplementary table S8). A human study [100] found that of 543 genes available for comparison, 358 genes were differentially expressed when comparing e-cigarette users with nonusers, the differences generally being consistent with immune suppression. Some effects were six times greater for e-cigarettes than for cigarettes. A comparison of cigarette smokers and e-cigarette users [101] showed that genes downregulated for both groups (i.e. common effects) tended to be ones involved in cilia assembly and movement; PCR validation indicated that both e-cigarettes and cigarettes interfered with ciliated cells in the airway epithelium. GANAPATHY et al. [102] found a dose-dependent effect of e-cigarettes on DNA damage. Two related studies $[103,104]$ confirmed effects for impaired cell functioning and 
increased interference with DNA repair mechanisms. Two of the studies [99, 102] found that the effect of e-cigarettes on DNA damage and other processes was comparable to effects observed for cigarettes.

In the most recent work, an in vivo human study [105] found larger numbers of differentially expressed transcripts in exclusive smokers and e-cigarette users compared to controls (1726 versus 1152). Only 299 of the differences were common to smokers and e-cigarette users, indicating their effects were through largely different mechanisms. Song et al. [106] analysed cells from bronchoscopies and found a large number of differentially expressed transcripts $(n=2452)$ for e-cigarette users and smokers compared to nonsmokers. Inflammation processes were implicated, in that e-cigarette users had higher inflammatory infiltrates than nonsmokers, but levels tended to be lower than for smokers.

\section{Summary of laboratory studies}

Laboratory studies have shown e-cigarettes to have effects on four biological processes that are relevant for respiratory disease. Evidence is found for exposure to e-cigarette liquid or aerosol producing cytotoxic effects and oxidative stress. Results for inflammation are less consistent, but effects on cytokines and other indices of inflammation have been found in several studies. Both cell studies and animal models indicate that bacterial virulence and indices of susceptibility to infection are increased by e-cigarette exposure and that bacteria- and virus-infected animals show higher morbidity and mortality when they are exposed to e-cigarette aerosol. Finally, studies of genetic variables have found e-cigarettes to cause DNA damage and e-cigarette use to suppress genes involved in immune function, with pathways that can be distinct from those found for cigarettes. While comments have been made about specific aspects for some of the studies [107-110], the finding of biological effects for e-cigarettes across four outcome domains in both cell cultures, animal models and human studies shows a replicable body of findings linking e-cigarettes to several biological processes involved in the pathogenesis of respiratory disease in humans.

\section{General discussion}

The aim of this article is to provide an integrative review of the relation between e-cigarette use and respiratory health outcomes by considering findings from epidemiological studies together with evidence from laboratory studies. Our epidemiological review has demonstrated a consistent association of e-cigarette use with respiratory disorder in multiple independent studies with representative samples of adolescents and adults. Laboratory studies show e-cigarette effects on four biological processes relevant for respiratory disorder and include both in vitro and in vivo studies. Risk-promoting effects have been found across four biological domains using fairly different paradigms. Thus, there is considerable evidence for a relation between e-cigarette use and respiratory disorder. In the following sections we discuss methodological issues relevant for drawing conclusions.

\section{Alternative explanations}

Studies have dealt with several alternative explanations for findings about e-cigarettes. Epidemiological studies have controlled for a number of covariates (e.g. age, sex, race/ethnicity, obesity, own smoking, second-hand smoke exposure) and these were somewhat different ones across studies, hence an argument of potential omitted-variable bias is harder to sustain. Also, significant findings from longitudinal studies and findings of associations of e-cigarette use with respiratory disease among persons who had never smoked cigarettes work against interpretations of reverse causation. While it has sometimes been suggested that persons with respiratory disease might use e-cigarettes for therapeutic purposes, it is difficult to see why they would do this given that e-cigarette aerosol has lung irritant effects (e.g. $[69,80,84,90,92,111])$.

\section{Difference from controls and from cigarettes}

Laboratory studies consistently find that e-cigarette conditions significantly elevate adverse biological effects compared with clean-air or comparable control conditions, and a number of studies show e-cigarette effects comparable to those for cigarette smoke (supplementary tables S5-S8). Thus, there is consistent evidence from controlled experiments that e-cigarettes, while not having the high levels of known carcinogens associated with cigarettes [65], still can have adverse consequences from a respiratory standpoint. These concerns are supported in the present review by data showing a consistent association of e-cigarette use with respiratory disorder in large general-population samples of adolescents and adults (tables 1 and 2).

\section{Relation to Hill's criteria}

Bradford Hill's criteria were developed to provide guidance for inferring causality from epidemiological research [112] and have had an enduring impact on multiple areas of research [113-115]. Our summary of how the evidence meets these criteria is as follows. 


\section{Consistency}

Our epidemiological review shows a significant association between e-cigarette use and respiratory disorder in 23 out of 24 studies, making this a highly consistent finding. In laboratory research, e-cigarettes have been found to affect disease-relevant biological processes in 35 independent studies using different methods and paradigms. Although nonsignificant conditions and null studies can be found, the consistency of confirmatory evidence is substantial.

\section{Temporality}

Finding the predictor to occur before the onset of a disease condition is a crucial criterion [112]. Prospective analyses have shown that e-cigarette use predicts onset of asthma or COPD among initially disease-free cases or worsening of respiratory symptoms over time among those with illness, controlling for baseline level $[46,52]$. Together with findings from laboratory experiments where the exposure precedes the outcome, this evidence gives support for meeting the temporality criterion.

\section{Dose-response gradient}

A graded relation between level of exposure and probability of illness is another important criterion. In the present review we have noted many instances of dose-response relationships in laboratory studies. Epidemiological studies typically do not have continuous exposure data, but several have noted more recent use or greater number of days used in past month to be related to higher likelihood of respiratory disease $[32,42,47,51,52]$. Thus, this criterion is met to some extent, although not uniformly across the types of studies discussed.

\section{Biological plausibility}

We have shown in detail how e-cigarettes affect biological processes known to be important in the pathogenesis of human respiratory disease. This is based on experimental studies testing specific biological processes and controlled-infection studies using pathogens such as influenza and pneumonia, which are significant disease problems among humans. Thus, the finding of an association of e-cigarette use with respiratory disorder in epidemiological studies is biologically plausible because respiratory disease can develop through these mechanisms, although animal models may not directly mimic human disease.

\section{Strength of relationship}

Our meta-analysis of epidemiological studies showed the unique association between e-cigarette use and respiratory disease is an adjusted odds ratio of 1.39 for asthma and 1.45 for COPD. Whether this would be characterised as a large or small effect size is somewhat arbitrary [116], but an important consideration is that even a moderate effect size spread across a large publication can have substantial public health impact. We think the strength of relationship is such as to warrant concern about public health consequences.

\section{Coherence with existing knowledge}

HiLl [112] argued that a cause-effect interpretation of data should not seriously conflict with generally known facts about the natural history and biology of the disease. Based on the evidence presented here and existing knowledge about the aetiology of respiratory disease (e.g. [28, 74]), the postulate of a relationship between e-cigarette use and respiratory disease does not seriously conflict with existing knowledge.

It should be noted that a recent development is an outbreak of severe lung disease termed e-cigarette- or vaping-associated lung injury (EVALI) [117-121]. Importantly, the e-cigarettes that these persons had been using typically contained tetrahydrocannabinol (THC) [122], and this has been accepted as one defining characteristic in the outbreak. In addition, vitamin E acetate (VEA) was detected in bronchoalveolar lavage fluid in most cases where this was available [123], and a VEA mechanism has been supported in an animal model [124]. Thus, VEA is strongly suspected of being a causal factor for EVALI, although a small minority of affected patients deny having vaped THC [125], and other constituents have been suggested for consideration [126]. Whether EVALI results from processes similar to or different from those discussed here, such as oxidative stress [126, 127], or from alternative mechanisms such as lipid deposition [128, 129], is unknown at present. The most recent brands of e-cigarettes have cytotoxic effects and disrupt lung functioning $[71,130,131]$, suggesting that the issues we have noted may be contributory for EVALI. Several mechanisms should be considered, and continuing epidemiological surveillance and laboratory research are needed to determine the social and biological effects of current electronic delivery systems.

\section{Conclusion and further research}

In summary, we find that Hill's criteria have been adequately satisfied and the evidence supports the conclusion of a real relationship between e-cigarettes and respiratory disorders. There are still many 


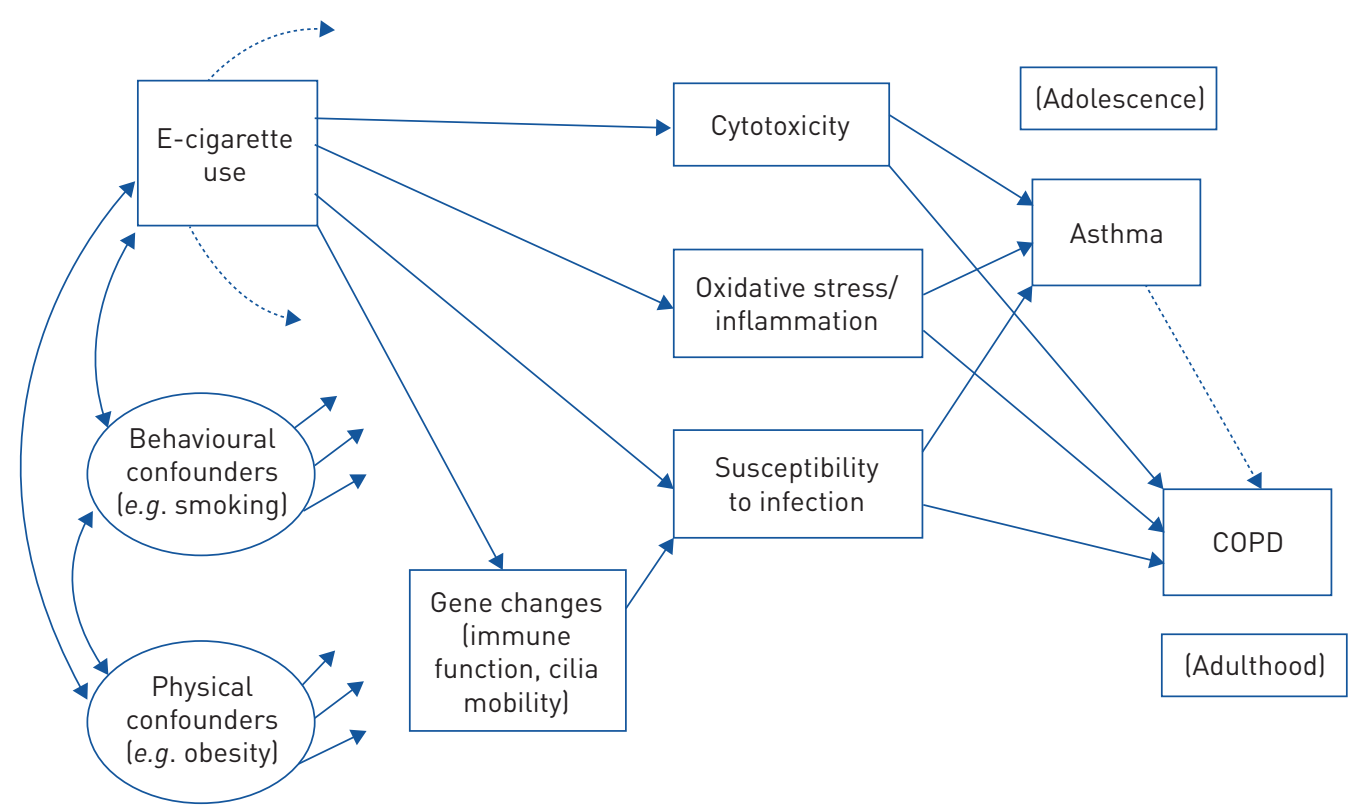

FIGURE 3 Heuristic model for exploring relationship of e-cigarettes to respiratory outcomes.

questions that need to be clarified, for example whether e-cigarette use is more related to onset of disease or to exacerbation of existing symptomatology, or whether there are different types of effects at different ages. However, we think the state of the evidence is sufficient to warrant concern about the population impact of e-cigarettes [132].

The research discussed here has generally used good experimental parameters, but further research is needed to solidify knowledge about the health consequences of e-cigarettes. Toward this end, we integrate the findings in a heuristic model of e-cigarette use and respiratory disorder (figure 3). This model is testable based on methods used in prior research on behavioural consequences of e-cigarette use [10, 130]. It is not clear whether the processes we have discussed work independently or in tandem, and the model aims to clarify tests of this question.

We can suggest that e-cigarette use may affect susceptibility to infection indirectly through altering expression of genes involved in immune-system function and ciliary mobility, whereas effects of e-cigarettes on cytotoxicity and oxidative stress may occur through biochemical effects on lung or airway membranes. All three processes are hypothesised to increase the likelihood of asthma and/or COPD, possibly at different ages. Our model recognises that other risk factors for respiratory disease (e.g. cigarette smoking and obesity) have their own effects on outcomes and need to be included as covariates in research on e-cigarettes. Direct effects from e-cigarette use to asthma or COPD, not mediated through the specified biological processes, are possible in principle and are testable in appropriately designed studies. Whether direct or indirect effects are found, more would be learned by using such models to study how e-cigarette use is related to respiratory outcomes.

Epidemiological studies have consistently noted that dual users have significantly more respiratory symptomatology compared with exclusive e-cigarette users or exclusive smokers. While e-cigarette use tends to be correlated with smoking, they are not interchangeable and they produce additive effects. Laboratory studies of genetic expression also show that effects of e-cigarettes occur in part through different biological pathways than cigarettes. E-cigarette use does not merely parallel effects of smoking, but contributes independently to risk. Thus there is every reason to further pursue these questions in research conducted among smokers as well as nonsmokers.

Author contributions: All authors contributed to the conception and design of the manuscript and the acquisition, analysis, and interpretation of data. All authors contributed to drafting the manuscript or critical revision for important intellectual content. All authors approve the final submitted version.

Conflict of interest: S.S. Soneji has nothing to disclose. K. Choi has nothing to disclose. I. Jaspers has nothing to disclose. E.K. Tam has nothing to disclose. T.A. Wills reports grants from National Cancer Institute (P30 CA071789), during the conduct of the study. 
Support statement: This work was supported by the National Cancer Institute (grant: P30 CA071789). Funding information for this article has been deposited with the Crossref Funder Registry.

\section{References}

1 Wang TW, Gentzke A, Sharapova S, et al. Tobacco product use among middle and highschool students - United States, 2011-2017. MMWR Morb Mortal Wkly Rep 2018; 67: 629-633.

2 Schulenberg JE, Johnston LD, O'Malley PM, et al. Monitoring the Future: National Survey Results on Drug Use, 1975-2018. Vol. II. College Students and Adults Ages 19-60. Ann Arbor: Institute for Social Research, University of Michigan, 2019.

3 Miech RA, Johnston LD, O'Malley PM, et al. Adolescent vaping and nicotine use in 2017-2018: U.S. national estimates. N Engl J Med 2019; 380: 192-193.

$4 \quad$ Cullen KA, Gentzke AS, Sawdey MD, et al. E-cigarette use among youth in the United States, 2019. JAMA 2019; 322: 2095-2103.

5 Murthy VH. E-cigarette use among youth and young adults: a major public health concern. JAMA Pediatr 2017; 171: 209-210.

6 Thorndike AN. E-cigarette use by young adult nonsmokers: next-generation nicotine dependence? Ann Intern Med 2019; 170: 70-71.

Besaratinia A, Tommasi S. Vaping: a growing global health concern. EClinicalMedicine 2019; 17: 100208.

Perez M, Crotty Alexander LE. Why is vaping going up in flames? Ann Am Thorac Soc 2020; 17: 545-549.

Glantz SA, Bareham DW. E-cigarettes: use, effects on health, risks, and policy implications. Ann Rev Public Health 2018; 39: 215-235.

10 Soneji S, Barrington-Trimis JL, Wills TA, et al. Association between initial use of e-cigarettes and subsequent cigarette smoking among adolescents and young adults: a systematic review and meta-analysis. JAMA Pediatr 2017; 171: 788-797.

11 National Academies of Sciences, Engineering, and Medicine. Public Health Consequences of E-cigarettes. Washington, DC, National Academies Press, 2018.

12 Landman S, Dhaliwal I, Mackenzie CA, et al. Life-threatening bronchiolitis related to electronic cigarette use in a Canadian youth. CMAJ 2019; 191: E1321-E1331.

13 Hua M, Talbot P. Potential health effects of electronic cigarettes: a systematic review of case reports. Prev Med Rep 2016; 4: 169-178.

14 Arter ZL, Wiggins A, Hudspath C, et al. Acute eosinophilic pneumonia following e-cigarette use. Resp Med Case Rep 2019; 27: 100825 .

15 Bradford LE, Rebuli ME, Ring BJ, et al. Danger in the vapor? ECMO for adolescents with status asthmaticus after vaping. J Asthma 2020; 57: 1168-1172.

16 Itoh $\mathrm{M}$, Aoshiba $\mathrm{K}$, Herai $\mathrm{Y}$, et al. Lung injury associated with electronic cigarettes inhalation diagnosed by transbronchial lung biopsy. Respir Case Rep 2017; 6: e00282.

17 Sommerfeld CG, Weiner DJ, Nowalk A, et al. Hypersensitivity pneumonitis and acute respiratory distress syndrome from e-cigarette use. Pediatrics 2018; 141: e20163927.

18 Lange P, Celli B, Agustí A, et al. Lung-function trajectories leading to chronic obstructive pulmonary disease. N Engl J Med 2015; 373: 111-122.

19 Santillan AA, Camargo CA, Colditz GA. A meta-analysis of asthma and risk of lung cancer (United States). Cancer Causes Control 2003; 14: 327-334.

20 Tagiyeva N, Devereux G, Fielding S, et al. Outcomes of childhood asthma and wheezy bronchitis: 50-year cohort study. Am J Respir Crit Care Med 2016; 193: 23-30.

21 Bhatnagar A. E-cigarettes and cardiovascular disease risk: evaluation of evidence, policy implications, and recommendations. Curr Cardiovasc Risk Rep 2016; 10: 24.

22 Bold KW, Krishnan-Sarin S, Stoney CM. E-cigarette use as a potential cardiovascular disease risk behavior. Am Psychol 2018; 73: 955-967.

23 Chen H, Li G, Chan YL, et al. Maternal e-cigarette exposure in mice alters DNA methylation and lung cytokine expression in offspring. Am J Respir Cell Mol Biol 2018; 58: 366-377.

24 McGrath-Morrow SA, Hayashi M, Aherrera A, et al. The effects of electronic cigarette emissions on systemic cotinine levels, weight and postnatal lung growth in neonatal mice. PLoS One 2015; 10: e0118344.

25 Nguyen T, Li GE, Chen $\mathrm{H}$, et al. Maternal e-cigarette exposure results in cognitive and epigenetic alterations in offspring in a mouse model. Chem Res Toxicol 2018; 31: 601-611.

26 Zakarya R, Adcock I, Oliver BG. Epigenetic impacts of maternal tobacco and e-vapour exposure on the offspring lung. Clin Epigenetics 2019; 11: 32.

27 Chun LF, Moazed F, Calfee CS, et al. Pulmonary toxicity of e-cigarettes. Am J Physiol Lung Cell Mol Physiol 2017; 313: L193-L206.

28 Clapp PW, Jaspers I. Electronic cigarettes: their constituents and potential links to asthma. Curr Allergy Asthma Rep 2017; 17: 79.

29 Wills TA, Knight R, Williams R, et al. Risk factors for exclusive e-cigarette use and dual e-cigarette and tobacco use in adolescents. Pediatrics 2015; 135: e43-e51.

30 Wills TA, Gibbons FX, Sargent JD, et al. How is the effect of e-cigarette use on smoking onset mediated: a longitudinal analysis. Psychol Addict Behav 2016; 30: 876-886.

31 Wills TA, Knight R, Sargent JD, et al. Longitudinal study of e-cigarette use and onset of cigarette smoking among high school students in Hawaii. Tob Control 2017; 26: 34-39.

32 Cho JH, Paik SM. Association between electronic cigarette use and asthma among high school students in South Korea. PLoS One 2016; 11: e0151022.

33 Kim SY, Sim S, Choi HG. Active, passive, and electronic cigarette smoking is associated with asthma in adolescents. Sci Rep 2017; 7: 17789.

34 Lee A, Lee SY, Lee K-S. The use of heated tobacco products is associated with asthma, allergic rhinitis, and atopic dermatitis in Korean adolescents. Sci Rep 2019; 9: 17699. 

Hong Kong. JAMA Pediatr 2016; 170: 89-91.

36 Choi K, Bernat D. E-cigarette use among Florida youth with and without asthma. Am J Prev Med 2016; 51: 446-453.

37 Fedele DA, Barnett TE, Dekevich D, et al. Prevalence of and beliefs about electronic cigarettes and hookah among high school students with asthma. Ann Epidemiol 2016; 26: 865-869.

38 Bayly JE, Bernat D, Porter L, et al. Secondhand exposure to aerosols from electronic nicotine delivery systems and asthma exacerbations among youth with asthma. Chest 2019; 155: 88-93.

39 Larsen K, Faulkner GEJ, Boak A, et al. Looking beyond cigarettes: are Ontario adolescents with asthma less likely to smoke e-cigarettes, marijuana, waterpipes or tobacco cigarettes? Respir Med 2016; 120: 10-15.

40 Schweitzer RJ, Wills TA, Tam E, et al. E-cigarette use and asthma in a multiethnic sample of adolescents. Prev Med 2017; 105: 226-231.

41 Wills TA, Choi K, Pagano I. E-cigarette use associated with asthma independent of cigarette smoking and marijuana in a 2017 national sample of adolescents. J Adolesc Health 2020; 67: 524-530.

42 McConnell R, Barrington-Trimis JL, Wang $\mathrm{K}$, et al. Electronic cigarette use and respiratory symptoms in adolescents. Am J Respir Crit Care Med 2017; 195: 1043-1049.

43 Wang JB, Olgin JE, Nah G, et al. Cigarette and e-cigarette dual use and risk of cardiopulmonary symptoms in the Health eHeart Study. PLoS One 2018; 13: e0198681.

44 Wills TA, Pagano I, Williams RJ, et al. E-cigarette use and respiratory disorder in an adult sample. Drug Alcohol Depend 2019; 194: 363-370.

45 Osei AD, Mirbolouk M, Orimoloye OA, et al. The association between e-cigarette use and asthma among never combustible cigarette smokers: Behavioral Risk Factor Surveillance System (BRFSS) 2016 \& 2017. BMC Pulm Med 2019; 19: 180 .

46 Bhatta DN, Glantz SA. Association of e-cigarette use with respiratory disease among adults: a longitudinal analysis. Am J Prev Med 2020; 58: 182-190.

47 Strong DR, Myers MG, Pulvers K, et al. Marijuana use among US tobacco users: findings from wave 1 of the Population Assessment of Tobacco Health (PATH) study. Drug Alcohol Depend 2018; 186: 16-22.

48 Perez M, Atuegwu NC, Mead EL, et al. Adult e-cigarette use associated with a self-reported diagnosis of COPD. Int J Environ Res Public Health 2019; 16: 3938.

49 Li D, Sundar IK, McIntosh S, et al. Association of smoking and electronic cigarette use with wheezing and related respiratory symptoms in adults: cross-sectional results from the Population Assessment of Tobacco and Health (PATH) study, wave 2. Tob Control 2020; 29: 140-147.

50 Osei AD, Mirbolouk M, Orimoloye OA, et al. Association between e-cigarette use and chronic obstructive pulmonary disease by smoking status: Behavioral Risk Factor Surveillance System 2016 and 2017. Am J Prev Med 2020; 58: 336-342.

51 Hedman L, Backman H, Stridsman C, et al. Association of electronic cigarette use with smoking habits, demographic factors, and respiratory symptoms. JAMA Netw Open 2018; 1: e180789.

52 Bowler RP, Hansel NH, Jacobson S, et al. Electronic cigarette use in US adults at risk for or with COPD: analysis from two observational cohorts. J Gen Intern Med 2017; 32: 1315-1322.

53 Brener ND, Billy JOG, Grady WR. Assessment of factors affecting the validity of self-reported health risk behavior among adolescents: a review of the literature. J Adolesc Health 2003; 33: 437-457.

54 Del Boca FK, Darkes J. The validity of self-reports of alcohol consumption: state of the science and challenges for research. Addiction 2003; 98: Suppl. 2, 1-12.

55 Brener ND, Kann L, McManus T, et al. Reliability of the 1999 Youth Risk Behavior Survey questionnaire. J Adolesc Health; 2002: 336-342.

56 Brener ND, Kann L, Shanklin S, et al. Methodology of the Youth Risk Behavior Surveillance System - 2013. MMWR Recomm Rep 2013; 62: 1-20.

57 Hu SS, Pierannunzi C, Balluz L. Integrating a multimode design into a national random-digit-dialed telephone survey. Prev Chronic Dis 2011; 8: A145.

58 Li C, Balluz LS, Ford ES, et al. A comparison of prevalence estimates for selected health indicators of chronic diseases or conditions from the Behavioral Risk Factor Survey Surveillance System, the National Health Interview Survey, and the National Health and Nutrition Examination Survey, 2007-2008. Prev Med 2012; 54: 381-387.

59 Pierannunzi C, Hu SS, Balluz L. A systematic review of publications assessing reliability and validity of the Behavioral Risk Factor Surveillance System (BRFSS), 2004-2011. BMC Med Res Methodol 2013; 13: 49.

60 Williams M, Villarreal A, Bozhilov K, et al. Metal and silicate particles including nanoparticles are present in electronic cigarette cartomizer fluid and aerosol. PLoS One 2013; 8: e57987.

61 Zhao J, Zhang Y, Sisler JD, et al. Assessment of reactive oxygen species generated by electronic cigarettes using acellular and cellular approaches. J Hazard Mater 2018; 344: 549-557.

62 Bals R, Boyd J, Esposito S, et al. Electronic cigarettes: a task force report from the European Respiratory Society. Eur Respir J 2019; 53: 1801151.

63 Ahmad S, Zafar I, Mariappan N, et al. Acute pulmonary effects of aerosolized nicotine. Am J Physiol Lung Cell Mol Physiol 2019; 316: L94-L104.

64 Behar RZ, Wang Y, Talbot P. Comparing the cytotoxicity of electronic cigarette fluids, aerosols and solvents. Tob Control 2018; 27: 325-333.

65 Goniewicz ML, Smith DM, Edwards KC, et al. Comparison of nicotine and toxicant exposure in users of electronic cigarettes and combustible cigarettes. JAMA Netw Open 2018; 1: e185937.

66 Erythropel HC, Jabba SV, DeWinter TM, et al. Formation of flavorant-propylene glycol adducts with novel toxicological properties in chemically unstable e-cigarette liquids. Nicotine Tob Res 2019; 21: 1248-1258.

67 Putzhammer R, Doppler C, Jakshcitz T, et al. Vapors of US and EU market leader electronic cigarette brands and liquids are cytotoxic for human vascular endothelial cells. PLoS One 2016; 11: e0157337.

68 Leigh NJ, Lawton RI, Hershberger PA, et al. Flavorings affect inhalation toxicity of aerosol generated from electronic nicotine delivery systems (ENDS). Tob Control 2016; 25: Suppl. 2, ii81-ii87. 
Anderson C, Majeste A, Hanus J, et al. E-cigarette aerosol exposure induces reactive oxygen species, DNA damage, and cell death in vascular endothelial cells. Toxicol Sci 2016; 154: 332-340.

Rowell TR, Reeber SL, Lee SL, et al. Flavored e-cigarette liquids reduce proliferation and viability in the CALU3 airway epithelial cell line. Am J Physiol Lung Cell Mol Physiol 2017; 313: L52-L66.

Omaiye EE, McWhirter KJ, Luo W, et al. High-nicotine electronic cigarette products: toxicity of JUUL fluids and aerosols correlates strongly with nicotine and some flavor chemical concentrations. Chem Res Toxicol 2019; 32: 1058-1069.

Hua M, Omaiye EE, Luo W, et al. Identification of cytotoxic flavor chemicals in top-selling electronic cigarette refill fluids. Sci Rep 2019; 9: 2782.

Escobar Y-NH, Nipp G, Cui T, et al. In vitro toxicity and chemical characterization of aerosol derived from electronic cigarette humectants using a newly developed exposure system. Chem Res Toxicol 2020; 33: 1677-1688. Hecker L. Mechanisms and consequences of oxidative stress in lung disease: therapeutic implications for an ageing populace. Am J Physiol Lung Cell Mol Physiol 2018; 314: L642-L653.

Scheffler S, Dieken H, Krischenowski O, et al. Evaluation of e-cigarette liquid vapor and mainstream cigarette smoke after direct exposure of primary human bronchial epithelial cells. Int J Environ Res Public Health 2015; 12: 3915-3925.

Schweitzer KS, Chen SX, Law S, et al. Endothelial disruptive proinflammatory effects of nicotine and e-cigarette vapor exposures. Am J Physiol Lung Cell Mol Physiol 2015; 309: L175-L187.

Crotty Alexander LEC, Drummond CA, Hepokoski M, et al. Chronic inhalation of e-cigarette vapor containing nicotine disrupts airway barrier function and induces systemic inflammation and multiorgan fibrosis in mice. Am J Physiol Regul Integr Comp Physiol 2018; 314: R834-R847.

Lerner CA, Sundar IK, Yao H, et al. Vapors produced by electronic cigarettes and e-juices with flavorings induce toxicity, oxidative stress, and inflammatory response in lung epithelial cells and in mouse lung. PLoS One 2015; 10: e0116732.

Ji EH, Sun B, Zhao T, et al. Characterization of electronic cigarette aerosol and its induction of oxidative stress response in oral keratinocytes. PLoS One 2016; 11: e0154447.

Larcombe AN, Janka MA, Mullins BJ, et al. The effects of electronic cigarette aerosol exposure on inflammation and lung function in mice. Am J Physiol Lung Cell Mol Physiol 2017; 313: L67-L79.

Chatterjee Shampa, Tao Jian-Qin, Johncola Alyssa, et al. Acute exposure to e-cigarettes causes inflammation and pulmonary endothelial oxidative stress in nonsmoking, healthy young subjects. Am J Physiol Lung Cell Mol Physiol 2019; 317: L155-L166.

Muthumalage T, Prinz M, Ansah KO, et al. Inflammatory and oxidative responses induced by exposure to commonly used e-cigarette flavoring chemicals and flavored e-liquids without nicotine. Front Physiol 2018; 8: 1130 .

Scott A, Lugg ST, Aldridge K, et al. Pro-inflammatory effects of e-cigarette vapor condensate on human alveolar macrophages. Thorax 2018; 73: 1161-1169.

Wu Q, Jiang D, Minor M, et al. Electronic cigarette liquid increases inflammation and virus infection in primary human airway epithelial cells. PLoS One 2014; 9: e108342. cytokines while increasing the virulence of colonizing bacteria. J Mol Med 2016; 94: 667-679.

Sussan TE, Gajghate S, Thimmulappa RK, et al. Exposure to electronic cigarettes impairs pulmonary anti-bacterial and anti-viral defenses in a mouse model. PLoS One 2015; 10: e0116861.

Gilpin DF, McGown K-A, Gallagher K, et al. Electronic cigarette vapour increases virulence and inflammatory potential of respiratory pathogens. Respir Res 2019; 20: 267.

Gómez A-C, Rodríguez-Fernández P, Villar-Hernández R, et al. E-cigarettes: effects in phagocytosis and cytokines response against Mycobacterium tuberculosis. PLoS One 2020; 15: e0228919. .

Madison M, Landers C, Gu B-H, et al. Electronic cigarettes disrupt lung lipid homeostasis and innate immunity independent of nicotine. J Clin Invest 2019; 129: 4290-4304.

Reidel B, Radicioni G, Clapp P, et al. E-cigarette use causes a unique innate immune response in the lung involving increased neutrophilic activation and altered mucin secretion. Am J Respir Crit Care Med 2018; 197: 492-501.

Garcia-Arcos I, Geraghty P, Baumlin N, et al. Chronic electronic cigarette exposure in mice induces features of COPD in a nicotine-dependent manner. Thorax 2016; 71: 1119-1129.

Ghosh A, Coakley RC, Masscenik T, et al. Chronic e-cigarette exposure alters the human bronchial epithelial proteome. Am J Respir Crit Care Med 2018; 198: 67-76.

Clapp PW, Lavrich KS, van Heusden CA, et al. Cinnamaldehyde in flavored e-cigarette liquids temporarily suppresses bronchial epithelial cell ciliary motility by dysregulation of mitochondrial function. Am J Physiol Lung Cell Mol Physiol 2019; 316: L470-L486.

Hickman E, Herrera CA, Jaspers I. Common e-cigarette flavoring chemicals impair neutrophil phagocytosis and oxidative burst. Chem Res Toxicol 2019; 32: 982-985.

Corriden R, Moshensky A, Bojanowski C, et al. E-cigarette use increases susceptibility to bacterial infection by impairment of human neutrophil chemotaxis, phagocytosis, and NET formation. Am J Physiol Cell Physiol 2020; 318: C205-C214.

Ghosh A, Coakley RD, Ghio AJ, et al. Chronic e-cigarette use increases neutrophil elastase and matrix metalloprotease levels in the lung. Am J Respir Crit Care Med 2019; 200: 1392-1401.

Higham A, Rattray NJW, Dewhurst JA, et al. Electronic cigarette exposure triggers neutrophil inflammatory responses. Respir Res 2016; 17: 56.

Clapp P, Pawlak E, Lackey J, et al. Flavored e-cigarette liquids and cinnamaldehyde impair respiratory innate immune cell function. Am J Physiol Lung Cell Mol Physiol 2017; 313: L278-L292.

$\mathrm{Yu}$ V, Rahimy M, Korrapati A, et al. Electronic cigarettes induce DNA strand breaks and cell death independently of nicotine in cell lines. Oral Oncol 2016; 52: 58-65.

Martin EM, Clapp PW, Rebuli ME, et al. E-cigarette use results in suppression of immune and inflammatory-response genes in nasal epithelial cells similar to cigarette smoke. Am J Physiol Lung Cell Mol Physiol 2016; 311: L135-L144. 
101 Moses E, Wang T, Corbett S, et al. Molecular impact of electronic cigarette aerosol exposure in human bronchial epithelium. Toxicol Sci 2017; 155: 248-257.

102 Ganapathy V, Manyanga J, Brame L, et al. Electronic cigarette aerosols suppress antioxidant defenses and induce significant oxidative DNA damage. PLoS One 2017; 12: e0177780.

103 Muthumalage T, Lamb T, Friedman M, et al. E-cigarette flavored pods induce inflammation, epithelial barrier dysfunction, and DNA damage in lung epithelial cells and monocytes. Sci Rep 2019; 9: 19035.

104 Lee H-W, Park S-H, Weng M-W, et al. E-cigarette smoke damages DNA and reduces repair activity in mouse lung, heart, and bladder as well as in human lung and bladder cells. Proc Natl Acad Sci USA 2018; 115: E1560-E1569.

105 Tommasi S, Caliri AW, Caceres A, et al. Deregulation of biologically significant genes and associated molecular pathways in the oral epithelium of electronic cigarette users. Int J Mol Sci 2019; 20: 738.

106 Song M-A, Freudenheim JL, Brasky TM, et al. Biomarkers of exposure and effect in the lungs of smokers, nonsmokers, and electronic cigarette users. Cancer Epidemiol Biomarkers Prev 2020; 29: 443-451.

107 Shields PG, Song M-A, Freudenheim JL, et al. Electronic cigarettes and the lung proteome. Am J Respir Crit Care Med 2018; 198: 1350-1351.

108 Tarran R, Ghosh A, Alexis N. Reply to Shields et al:: electronic cigarettes and the lung proteome. Am J Respir Crit Care Med 2018; 198: 1351-1352.

109 Jasper AE, Sapey E, Thickett D, et al. Comment on "E-cigarette use increases susceptibility to bacterial infection by impairment of human neutrophil chemotaxis, phagocytosis, and NET formation". Am J Physiol Cell Physiol 2020; 318: C704-C705.

110 Crotty Alexander LE, Meier A. Reply to Letter to the Editor: "Comment on 'E-cigarette use increases susceptibility to bacterial infection by impairment of human neutrophil chemotaxis, phagocytosis, and NET formation"'. Am J Physiol Cell Physiol 2020; 318: C706.

111 Kosmider L, Sobczak A, Prokopowicz A, et al. Cherry-flavored electronic cigarettes expose users to the inhalation irritant, benzaldehyde. Thorax 2016; 71: 376-377.

112 Hill AB. The environment and disease: association or causation? Proc R Soc Med 1965; 58: 295-300.

113 Hernán MA. The C-word: scientific euphemisms do not improve causal inference from observational data. Am J Public Health 2018; 108: 616-619.

114 Adami H-O, Berry CL, Breckenridge CB, et al. Toxicology and epidemiology: improving the science with a framework for combining toxicological and epidemiological evidence to establish causal inference. Toxicol Sci 2011; 122: 233-234.

115 Fedak KM, Bernal A, Capshaw ZA, et al. Applying the Bradford Hill criteria in the 21st century: how data integration has changed causal inference in molecular epidemiology. Emerg Themes Epidemiol 2015; 12: 14

116 Chen $\mathrm{H}$, Cohen $\mathrm{P}$, Chen S. How big is a big odds ratio? Interpreting the magnitudes of odds ratios in epidemiological studies. Comm Stat Simul Comput 2010; 39: 860-864.

117 Blagev DP, Harris D, Dunn AC, et al. Clinical presentation, treatment, and short-term outcomes of lung injury associated with e-cigarettes or vaping: a prospective observational cohort study. Lancet 2019; 394: 2073-2083.

118 Layden JE, Ghinai I, Pray I, et al. Pulmonary illness related to e-cigarette use in Illinois and Wisconsin - final report. N Engl J Med 2020; 382: 903-916.

119 Ghinai I, Pray IW, Navon L, et al. E-cigarette product use, or vaping, among persons with associated lung injury - Illinois and Wisconsin, April-September 2019. MMWR Morb Mortal Wkly Rep 2019; 68: 865-869.

120 Kalininskiy A, Bach CT, Nacca NE, et al. E-cigarette, or vaping, product use associated lung injury (EVALI): case series and diagnostic approach. Lancet Respir Med 2019; 7: 1017-1026.

121 Triantafyllou GA, Tiberio PJ, Zou RH, et al. Vaping-associated lung injury: a case series. Am J Respir Crit Care Med 2019; 200: 1430-1431.

122 Krishnasamy VP, Hallowell BD, Ko JY, et al. Update: characteristics of a national outbreak of e-cigarette, or vaping, product use-associated lung injury, United States, August 2019-January 2020. MMWR Morb Mortal Wkly Rep 2020; 69: 90-94.

123 Blount BC, Karwowski MP, Shields PG, et al. Vitamin E acetate in bronchoalveolar-lavage fluid associated with EVALI. N Engl J Med 2020; 382: 697-705.

124 Bhat TA, Kalathil SG, Bogner PN, et al. An animal model of inhaled vitamin E acetate and EVALI-like lung injury. N Engl J Med 2020; 382: 1175-1177.

125 Ghinai I, Navon L, Gunn JKL, et al. Characteristics of persons who report using only nicotine-containing products among interviewed patients with e-cigarette, or vaping, product use-associated lung injury - Illinois, August-December 2019. MMWR Morb Mortal Wkly Rep 2020; 69: 84-89.

126 Crotty Alexander LE, Ware L, Calfee C, et al. E-cigarette or vaping product use-associated lung injury: developing a research agenda. An NIH workshop report. Am J Respir Crit Care Med 2020; 202: 795-802.

127 Chand HS, Muthumalage T, Maziak W, et al. Pulmonary toxicity and the pathophysiology of electronic cigarette, or vaping product, use associated lung injury. Front Pharmacol 2020; 10: 1619.

128 Crotty Alexander LE, Bellinghausen AL, Eakin MN. What are the mechanisms underlying vaping-induced lung injury? J Clin Invest 2020; 130: 2754-2756.

129 Eissenberg T, Maziak W. Are electronic cigarette users at risk for lipid-mediated lung injury? Am J Respir Crit Care Med 2020; 201: 1012-1013.

130 Chaumont $\mathrm{M}$, van de Borne $\mathrm{P}$, Bernard $\mathrm{A}$, et al. Fourth-generation e-cigarette vaping induces transient lung inflammation and gas exchange disturbances: results from two randomized clinical trials. Am J Physiol Lung Cell Mol Physiol 2019; 316: L705-L719.

131 Erythropel HC, Davis LM, de Winter TM, et al. Flavor-solvent reaction products and menthol in JUUL e-cigarettes and aerosol. Am J Prev Med 2019; 57: 425-427.

132 Soneji SS, Sung H-Y, Primack BA, et al. Quantifying population-level benefits and harms of e-cigarette use in the United States. PLoS One 2018; 13: e0193328. 